\title{
Vaudeville and American Modernity
}

\section{Monod, David. Vaudeville and the Making of Modern Entertainment, 1890-1925. Chapel Hill: University of North Carolina Press, 2020. 288 pp. \$29.95 (paper), ISBN 978-1-4696-6055-4.}

\author{
Susan Ellen Kattwinkel \\ College of Charleston, Charleston, SC, USA \\ doi:10.1017/S1537781421000359
} Vaudeville has been a flourishing subject of theater scholarship for only the past twenty
years or so. Many academics have focused on questions of race and ethnicity, or on
specific performers, or on genres of acts, but the form's size and complexity, as well as its intersections with nearly every other theatrical genre, defy easy attempts to summarize it. David Monod's Vaudeville and the Making of Modern Entertainment, 1890-1925, takes on that challenge, offering a wide-ranging examination of the context and methods by which vaudeville became "the United States' first modern mass entertainment" (2). He continues the project of his earlier book, The Soul of Pleasure: Sentiment and Sensation in Nineteenth-Century American Mass Entertainment (2016), in documenting turn-of-thecentury vaudeville's democratization of consumerism, contemporary style, and culture. In six chapters flush with archival evidence, newspaper coverage, and 35,000 transcribed performance reviews from the period, Monod presents an exhaustive description of how the business and art of vaudeville fit into a broader cultural milieu.

Monod's introduction presents the two main threads that wind throughout the following six chapters: the business decisions that propelled vaudeville's rise and fall as mass entertainment and the aspects of verisimilitude that characterized its performance style. He also positions himself against existing vaudeville scholarship, emphasizing with scare quotes the terminology that has been used by performance scholars to highlight the transgressive elements of popular performance. But, as a whole, performance scholars generally view vaudeville as simultaneously subversive and conservative, much as Monod does. Similarly perplexing is his assertion that performance scholars often "describe synchronic relationships rather than a diachronic process" (8), an accusation that feels more like an ironic joke than considered analysis. While general historians will find the book a useful introduction to vaudeville's functions and to common interpretations of its interactions with broader U.S. culture, theater historians may be puzzled by the interpretations of performance style without reference to the vast library of performance theory. Nevertheless, all scholars will welcome Monod's encyclopedic evidence and his attempts to provide data analysis of such a large and unruly topic.

In his first chapter, Monod establishes his interpretation of vaudeville performers as urban style leaders, positing this as one of the main characteristics drawing in female and middle-class spectators and distinguishing vaudeville from variety. He discusses celebrity as one of the defining elements of vaudeville and notes that the burgeoning popular press 
made such celebrity possible. Vaudeville managers' reliance on celebrities to turn a profit was a key factor in the form's rise and fall and is a through line in the book. Monod's second chapter develops the book's most intriguing descriptions of the performance style of vaudevillians. He addresses concepts of authenticity and naturalness, analyzing performance techniques like narration and personalization to illustrate changing performance style. He connects these changes in style to other cultural shifts, like the ascendency of ragtime over coon songs, evolving views toward ethnic and racial stereotypes, and changing fashions in clothing and body type.

The concept of authenticity is perhaps the most intriguing theoretical through line of the book, and there is a rich existing conversation which Monod could have engaged with. Bernard Beckerman's Theatrical Presentation: Performer, Audience and Act (1990) and Michael Kirby's A Formalist Theatre (1990) are foundational texts that theorize modes of presentation in a wide range of performance forms, including vaudeville. More specifically, Lynn Voskuil's Acting Naturally: Victorian Theatricality and Authenticity (2004) and Daniel Schulze's Authenticity in Contemporary Theatre and Performance (2017) focus on Victorian British theater and twenty-first-century performance, respectively, but both ground their analyses in a history of authenticity performance, and cultural context, as Monod does.

Monod continues, in his third chapter, to examine naturalness in vaudeville performance, particularly in performers' attempts to wake up what was perceived as a numb and uninterested audience. The need to make spectators feel personally connected to the performers posed difficulties for acts that demanded focus on props or procedures, such as magicians and hypnotists, and often proved burdensome for celebrity performers. Although not its explicit focus, the chapter provides insight to how vaudeville managers aimed for a balance of novelty, familiarity, comfort, and excitement in their bills. Monod's fourth chapter, "Vaudeville Modernism," connects changing vaudeville performance techniques to emerging modernist interests and beliefs, here through examples of the vogue for novelty. Particularly engaging is a discussion of performers who deconstructed their own performances, either through the pretense of breaking character or by creating a play within a play, complicating what Monod calls "vaudeville's aesthetic of actuality" (125) and spectators' ability to distinguish between actor and character. He connects mental acts like illusionists to the scientific revolution of the age and notes how such acts changed to reflect popular beliefs on both science and the metaphysical.

Monod's final two chapters, "The Business of Mass Entertainment" and "Vaudeville Makes Its Exit," outline the rise and fall of vaudeville's circuits, chains, unions, and cartels in the most complete form since Arthur Wertheim's 2006 Vaudeville Wars. Monod explores how vaudeville's short-sighted and bigoted business decisions, as well as changing musical tastes and the rise of other forms of entertainment, contributed to the end of vaudeville as America's first mass entertainment. Monod's discussion of vaudeville's decline is complex, nuanced, and grounded in data, providing fertile ground for future scholars.

Monod never explains the very specific range of dates in the book's title. No watershed moments mark the years 1890 or 1925, and Monod's evidence spans from well before 1890 to after 1925 . The two very strong chapters on the business of big-time vaudeville mostly situate that development between those years, but many of the techniques he ascribes to the foundation of vaudeville (cleaning up and attracting female spectators, use of contemporary urban slang, sketches, bringing in overseas performers, etc.) were first done by variety and early vaudeville theaters in the 1870s and 1880s. Ultimately, despite his insistence that he is treading new ground, Monod's conclusions do not depart greatly 
from generally accepted interpretations of both vaudeville's popularity and its demise. Instead, he is most persuasive when discussing the effects of changing musical tastes on vaudeville and when connecting performance styles to the fashions and interests of modernity. Those arguments, along with the wealth of evidence on individual performers and business arrangements, will undoubtedly be of interest to scholars working in many areas of American popular culture. 